\title{
The Determinants of Agricultural Export: Cocoa and Rubber in Cote d'Ivoire
}

\author{
GRAFOUTE AMORO ${ }^{1} \&$ Yao Shen ${ }^{1}$ \\ ${ }^{1}$ School of International Business and Management, Shanghai University, China \\ Correspondence: GRAFOUTE AMORO, School of International Economic, Shanghai University, 99 Shangda \\ Road, Shanghai 200444, China. E-mail: graf_amoro@hotmail.com
}

Received: October 7, 2012 Accepted: November 7, 2012 Online Published: December 10, 2012

doi:10.5539/ijef.v5n1p228 URL: http://dx.doi.org/10.5539/ijef.v5n1p228

\begin{abstract}
As a large lake of natural endowment, most of African countries still have small and poorly developed domestic markets and must rely on foreign markets for the sale of their excess production. This study examined the factors that influence agricultural exports with specific reference to Cocoa and rubber. Secondary data was used for this study. Ordinary Least Squares regression (OLS) was used in analyzing the relevant data. The OLS findings revealed that rubber export is influenced significantly $(\mathrm{p}<0.05)$ by domestic rubber production $(\beta=68124.857)$, producer price $(\beta=10741.503)$, exchange rate $(\beta=-17078.957)$, domestic consumption $(\beta=-27094.147)$ and interest rate $(\beta=14991.565)$. For cocoa, the OLS shows that cocoa output $(\beta=0.847)$, domestic consumption $(\beta=-0.850)$ and rainfall $(\beta=44.074)$ significantly $(p<0.05)$ influence cocoa export. It is recommended that there should be value addition in respect of the cocoa being exported.
\end{abstract}

Keywords: Cote d'Ivoire, ordinary, Least Squares Regression (OLS), Structural Adjustment Programme (SAPS)

\section{Introduction}

As suppliers of raw materials to western economies, since independence, Africans countries' economies have continued to produce primarily crop for export . Thus agriculture still the most important single activity for the Africans peoples. In Cote d'Ivoire, about $70 \%$ of the total working population engaged in agricultural sector. Situated between Liberia and Ghana on the west coast of Africa, Côte d'Ivoire is first and foremost an agricultural country with agriculture one of the key pillars of the economy. The country is a great asset on the production and export of tropical products. Agriculture, forestry, and fisheries account for a substantial part of GDP and exports. Cote d'Ivoire produces $40 \%$ of the world's cocoa crop and is a major exporter of bananas, coffee, cotton, palm oil, pineapples, rubber, tropical wood products, and tuna. Consequently, the economy is highly sensitive to fluctuations in international prices for these products and to weather conditions. One of the most events in Cote d'Ivoire over the past decade was the devaluation of the currency in 1994 with the adoption of a Structural Adjustment Programme (SAP), supported by IMF and World Bank which was focused on export development regardless of their sectoral features, which reinforced the traditional exports of Côte d'Ivoire. However Cote d'Ivoire has been on crisis since 1999 which led to the destruction of economic infrastructure and the breakdown of government administration. The crisis brought a drastic fall in output, a substantial drop in employment, resulting in the loss of foreign investment and slow economic growth. In 2007, however undeniable progress was made in re-establishing the country's institutions, the recovery of the economy, as real GDP grew by 1.6 as compared to $0.9 \%$ in 2006 (see figure 1). In 2011 the crisis found a solution by the contested election won by the current president ALassane Ouattara.Although the country remained highly vulnerable it is better to notice that the agricultural sector still the pillar of the Economic, with contribution of 35 percent of the country's GDP and 66 percent of its export revenues, provided employment for about two-thirds of the national workforce. Cash crops, mainly cocoa and coffee account for nearly 50 percent of agricultural value added. Apart from cocoa and coffee it is critical to mention the rubber planting, which ranked at the fourth as exporter produce with the global revenue estimated at 162 billionsFCFA for 221000 tons. In 2009 Cote d'Ivoire ranked the first place in Africa and seventh in the world. The country is the first exporter of natural rubber. In 1999 the total superficies was 84000 hecters. The rubber processed transformation is doing by some companies such as $\mathrm{SAPH}, \mathrm{SOCB}$ and TRCI.Howver the country export the intermediaries' products in Foreign country .This Study therefore aims to examine the factors that can influence the export of cocoa and rubber with the following 
specific objectives: estimate net trade balance in agricultural trade, determine the possible factors influencing the rubber and cocoa export trade and finally profer some policy recommendations based on the findings of this investigation.

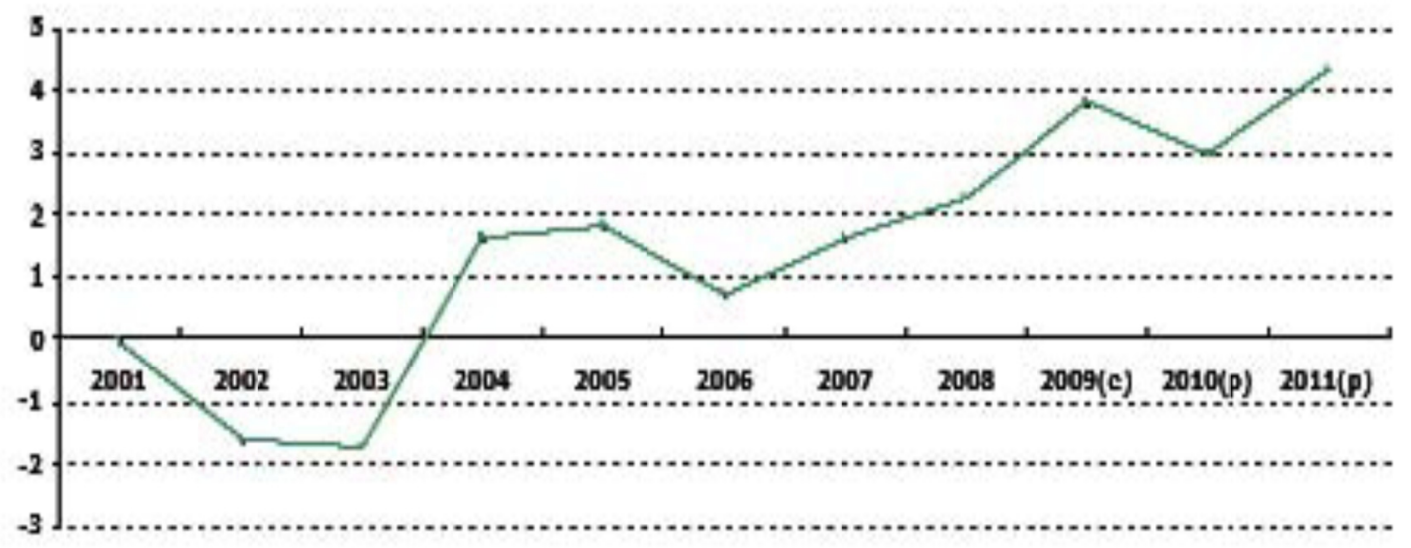

Figure 1. Recent Evolution of GDP growth rate in real terms

Source: IMF data and national sources; estimates (e) projections (p).

\section{Literature Review on the Determinants of Export}

According to Fleming and Blowes (2003), the Geographical factor can be identified as one the factors which influence export activities. Natural resources endowment is one of the variables that determine the export of country. The influence of this factor is well explained under the Heckser-Ohlin model that was used to determine International trade patterns. As a variable, the rainfall and climate condition enable Cote d'Ivoire to specialize in the tropical products exportation in which it has a comparative advantage. Thus the country benefit of many sources of water and rich soil, which favors primary crops, that economy is either not suited for huge local demand, due to the small and poorly developed domestic markets. Therefore the country rely on foreign markets entry for the sale of its products, which foreign market access is one the most critical determinants of exports according to Redding and Venable (2002), Fugaza (2004) and UNCTAD (2005).Market access refers to conditions determined by the legal and administrative framework imposed by the importing countries under internationally agreed trade rule that create the possibility of selling on foreign markets UNCTAD, (2006).

In contrast to foreign demand, a huge domestic demand impede an increase of the export related by ADB (2005),which reported a negative association between exports and growth rate of domestic demand in the Southeast Asian countries. Thus a variation in domestic demand pressure will affect the supply-side or availability for exports. Ball et.al (1966) also argued that at relatively high level of domestic demand, ceterus paribus, the quantity of resources devoted to export is lower. So, at lower domestic demand the surplus production leads to increased export volume. He further said that higher level of production is the main cause of export expansion since surplus output can be exhausted in international markets. Ngeno (1990) carried out a study on determinants of export and one of his findings was that export is positively related to output level since higher production leads to increased volume of exports. Musila (2004) analyzes the impact of the common market for Eastern and Southern Africa on Kenya export, and finds that export is associated with high volume exported and not high price for the product.

In the early 1970s, when Brazilian exports increased greatly, scholars and practitioners have investigated the country's export experience. In one of the pioneering studies on the topic, "Manufactured Export Promotion in a Semi-Industrialized Economy: The Brazilian case," Tyler (1973) suggested that the success of Brazilian industrial exports was a function of several independent variables such as real exchange rate, tax incentives, etc.Various studies have also shown that a fall in domestic prices due to exchange rate depreciation makes exports cheaper in the international market resulting into their increased demand. This mean the depreciation or devaluation of one country currency enables an increase demand of its exportation products. In Tanzania, a time series study on Non Traditional Exports (NTE) found a statistically significant relationship between real devaluation and export growth of (NTE).Studies in Ghana and India by Fosu(1992) and Sharma(2001) 
respectively have show that real exchange rate has a significative negative relationship with export. However a good producer price matching with export price has a positive significance on the export. Tijani et al (1999) employed cointegration and error correction model to estimate export supply function in Nigeria using time series data that span more than three quarters of the 20th century. The results indicate that weather effect is stationary while producer price and hectare planted to cocoa have a long run equilibrium relationship with cocoa export. This findings is significant to the present study as the results established it that producer price has a long run equilibrium relationship with the rubber export. The economic justification is that ,high producer price lead to accumulation of ample revenue to producers as a result resources are diverted from sectors that have low return to sector that promise high payment at that time consequently, high price induced producers to increase production of the given product and thus assured the supply and availability of products to export.

Regarding to the rainfall which has a positive significance effect on the yield of cocoa crop, this research find its significance to the previous finding where Akintola (1983), studying the effects of agro climatic factors on some selected crops in Ibadan. Following his correlation and regression analysis, the responsiveness of each crop yield to specific agro climatic variables (rainfall, temperature, sunshine and humidity) was determined. Based on his findings, it was known that rainfall has statistically significant effect on yields of rice, cowpea, yam, cocoa and rubber crops.

\section{Methodology}

The data for this study were obtained from secondary sources. They include the following; Food and agricultural organization (FAO), reputable journals and the Internet; and supplemented with primary data as Collected by the National Research center of Agronomy (CNRA) and Ministry of Agriculture (MINAGRI). The observation of this study is categorized as follow The pre-1970 period(1961-1969), pre-SAP period (1970-1985), SAP period (1986-1994) and the post-SAP period (1995-2005).The pre-1970 period witnessed a minimum direct government intervention in agricultural development. The pre-Structural Adjustment Programme (SAP) era witnessed an increasing migration of able-bodied youths from the rural to urban areas. The Structural Adjustment Programme period was the era SAP was introduced in Cote d'Ivoire. The post- Structural Adjustment Programme era is a period that witnessed activities in the agricultural sector after the Structural Adjustment Programme .Ordinary least squares (OLS) method was used to determine variables affecting export of cocoa and natural rubber. The function is stated as:

$$
L n X t=\beta_{0}+\beta_{1} \ln Q t+\beta_{2} \ln P t+\beta_{3} \ln W t+\beta_{4} \ln E X t+\beta_{5} \ln D c t+\beta_{6} \ln R t+\beta_{7} \ln \operatorname{In} t+\mu_{t}
$$

With $\mathrm{Qt}>0 ; \mathrm{Pt}>0 ; \mathrm{Wt}>0$; EXt $<0$; $\mathrm{Dct}<0$; Int $>0$ or $\operatorname{Int}<0$

$\mathbf{X t}=$ natural rubberlcocoa export quantity

(Tons) between 1970 and 2005

$\mathbf{Q t}=$ quantity of natural rubberlcocoa output

(Tons) between 1970 and 2005

$\mathbf{P t}=$ average producer price of natural rubber

Or cocoa (F/tons) between 1970 and 2005

$\mathbf{W} \mathbf{t}=$ average world market price of natural

rubberlcocoa (F\tons) between 1970 and 2005

$\mathbf{E X t}=$ exchange rate (FCFA to 1 U.S. dollar)

Between 1970 and 2005

Det $=$ domestic consumption (tons) of cocoa

$\mathbf{R t}=$ average total rainfall (mm/year) in major producing

Region between 1970 and 2005

Int=Interest rate (\%) between 1970 and 2005

\subsection{Hypothesis to Be Tested}

This study is testing the hypothesis zero influence of independent variables to dependent variable. It attempt to find out whether the independent variables have significant impact on dependent variable or not, that is $\beta_{j}$ is significantly equal to zero or not. This hypothesis can be written as;

$\mathrm{H}_{0}: \beta_{j}=0$ 
$\mathrm{H}_{\mathrm{i}}: \beta_{j} \neq 0$

\section{Results}

Average Net Trade Balance during Different Periods in Cote d'Ivoire

Table 1 shows the average net trade balance during the 4 different periods. The average net trade balance for total agricultural products on value at base year price (1000 US \$) from 1970 to 2004 range from $-178,149.11$ to $764,819.73$.

Table 1. Average net trade balance during different Periods in Cote d'ivoire

\begin{tabular}{ll}
\hline $\begin{array}{l}\text { Period Net } \\
\text { ('000 US\$) }\end{array}$ & trade balance \\
\hline $1961-1969$ (pre-1970) & $842,767.59$ \\
$1970-1985$ (pre-SAP) & $-178,149.11$ \\
$1986-1994$ (SAP) & $-265,614.67$ \\
$1995-2004$ (post-SAP) & $-764,819.73$ \\
\hline
\end{tabular}

Source: Computed from FAO Database, 2006.

\subsection{Determinants of Cocoa Export}

The result of the OLS regression is presented in Table 2.Regression analysis was carried out using log linear function. Log Linear function was used as it fits the model based on having the highest number of significant variables affecting cocoa export and the highest adjusted $\mathrm{R}^{2}$ value. The adjusted $\mathrm{R}^{2}$ was 0.789 , implying that the independent variables explain $78.90 \%$ of the total variation in cocoa export. The value was significant at $1 \%$ for cocoa production $(\mathrm{mt})(\beta=0.847)$ and domestic consumption $(\mathrm{mt})(\beta=-0.850)$. The $\mathrm{F}$-value $(18.634 ; \mathrm{P}<0.05)$ is significant at $1 \%$, implying that the model is significant.

Table 2. Ordinary least square estimates for cocoa export

\begin{tabular}{lccc}
\hline Variable & Coefficients & t-statics & Prob. \\
\hline Constant & -32424.547 & -0.870 & 0.392 \\
Cocoa output (mt) & 0.847 & 6.87 & 0.000 \\
Producer price of cocoa (F/mt) & 0.175 & 0.639 & 0.529 \\
World Price of cocoa (F/MT) & -1.253 & -0.341 & 0.736 \\
Exchange Rate & -76.819 & -0.343 & 0.735 \\
Domestic consumption (mt) & $-0.850^{*}$ & -8.019 & 0.000 \\
Interest rate (\%) & -418.779 & -0.634 & 0.532 \\
\hline
\end{tabular}

Source: Computed from data

$\mathrm{F}=18.634$;

Adjusted $\mathrm{R}^{2}=0.789$

*Significant at 1 percent

\subsection{Determinants of Rubber Export}

The result of the OLS method is presented in table 3. The log function best fit the model as it has the highest number of significant variables affecting rubber export and high-adjusted $R^{2}$ value. The adjusted $R^{2}$ was 0.838 ; Implying that the independent variables explain $83.80 \%$ of the total variation in the rubber export. The value was significant at $1 \%$ for rubber production $(\mathrm{mt})(\beta=68124.857)$, producer price $(\mathrm{F} / \mathrm{mt})(\beta=10741.503)$, exchange rate $(\beta=-17078.957)$,domestic consumption (mt) $(\beta=-27094.147)$ and interest rate $(\%)(\beta=14991.565)$. The $F$ value $(30.085 ; \mathrm{P}<0.05)$ is significant at $1 \%$, implying that the model was significant. 
Table 3. Ordinary least squares estimates for rubber export

\begin{tabular}{lcrr}
\hline Variable & Coefficients & T-statistics & Prob \\
\hline Constant & -731123.324 & -1.721 & 0.094 \\
Rubber Production (mt) & $68124.857^{*}$ & 8.647 & 0.000 \\
Price of Rubber (F/mt) & $10741.503^{*}$ & 2.745 & 0.009 \\
World Price of Rubber (F/mt) & 1798.804 & 0.322 & 0.749 \\
Exchange Rate & $-17078.957^{*}$ & -2.71 & 0.010 \\
Domestic consumption(mt) & $-27094.147^{*}$ & -10.36 & 0.000 \\
Interest rate (percent)* & $14991.565^{*}$ & 4.578 & 0.000 \\
\hline
\end{tabular}

Source: Computed from data

F value 30.085

Adjusted R2 $=0.838$

*Significant at 1 percent.

\section{Discussion}

The net trade balance value shows that agriculture remains a deficit trade balance. During the pre-1970 era, Cote d'Ivoire was involved in the exports of its agricultural products notably cocoa, natural rubber and palm oil. This contributed immensely to foreign earnings for the country. The implication of net exports shows that agricultural exports can adequately finance agricultural imports. Generally, the net trade balance value shows that Cote d'Ivoire remains a net importer with regards to agriculture. In summary, based on the results of table 1, in which net export values for the different period studied had negative values, it can be concluded that agricultural exports cannot finance agricultural imports. The positive sign for the cocoa production implies that an increase in production will lead to an increase in export. Conversely, a reduction in domestic consumption of cocoa will lead to an increase in the export of cocoa. The appropriate sign on rubber production is positive; it implies that an increase in production will stimulate an increase in export. The producer's price was also significant and has a positive sign, which is similar to the prediction above that an increase in farm gate price will result in an increase in export. This is in agreement with Okoruwa et al. (2003), who reported that an increase in producer's price of rubber will lead to an increase in export of rubber. The implication is that an increase in the producer's price of rubber to match world price will encourage maintenance of rubber farms and increased output. However a gap between export price and farm gate price discourage the rubber farmers from fully participating in rubber or cocoa production.

The official exchange rate was significant but has a negative sign. This finding is in agreement with Mesike (2005) who also reported a negative relationship between rubber export and exchange rate. This implies that the lower exchange rate that occurred during the devaluation of domestic currencies led to increased exports. Domestic consumption has a negative relationship with rubber export. This implies that a reduction in domestic consumption will lead to an increase in export supply and vice-versa

\section{Conclusion}

The African countries exports of agricultural products continue to be vital for the overseas population and their economies. And however although African countries earned substantial foreign exchange from their exports, major fluctuations in the export earnings have raised concern about their country's future growth potentials and self-sustainability. This study has established the major or significant determinants of cocoa and natural rubber exports in cote d'Ivoire,where export volume of Cocoa is crucial, estimated at 1.334000 million, while rubber export quantity account for 200652 tons in 2006.

\section{Recommendations}

The result of the study showed that output domestic consumption, interest rate, producer price and exchange rate have key roles to play in the export of cocoa and natural rubber in Cote d'Ivoire. In order to improve the export supply of the two cash crops, the following steps are necessary. Firstly as a small open economy in relation to the rest of the world, Cote d'Ivoire economic performance is sensitive to international market shocks. Consequently, stabilization policies that will enhance export promotion and productivity be implemented and sustained. Government policies will be canvassed to transform the composition of Ivoirian's export. Thus to achieve that goal, the country should re-invest its exports revenues in agro processing equipment $\&$ technologies and human capital. This will attract more revenue than raw cocoa. This will also stimulate local consumption. 
Conservation and rehabilitation programmes for rubber should be organized in areas where degradative processes are about to set in. Also, uncontrolled felling of rubber trees should be checked and farmers encouraged through appropriate pricing mechanisms, to replant the cleared and rehabilitate the old rubber plantations. Cote d'Ivoire should ensure that there is only a small margin between the producer prices and world price of rubber and cocoa, so that the farmers can benefit substantially from international market.

\section{References}

African Economic outlook AFDB/OECD. (2008).

Akintola, J. O. (1983). An Analysis of the effects of Agroclimatic factors on Foods crops yields in IBADAN area of Oyo State. An Unpublished PHD Thesis departement of Agricultural economics University of IBADAN.

Ball, R. M. (1966). The Relationship between U.K Export Performance in Manufactures and the internal pressure of Demand. Economic Journal, 76, 501-518.

Fleming, E. A. (2003). An Assessment of commodity Export Performance in South Pacific Countries, 1960 to 1999. University of New England Graduate School of Agricultural and Resource Economics, Working Paper No 2003-3.

Fleming, E. A. (2003). An Assessment of Commodity Export Performance in South Pacific Countries, 1960 to 1999. University of New England Graduate School of Agricultural and Resource Economics, working paper No2003-3.

Fosu, K. Y. (1992). The Real exchange rate and Ghana'sagricultural exports. African Economic Research consortium Research Paper 9.

Fugaza, M. (2004). Export Performance and Its Determinant: Supply and Demand Constraints. Policy Issues on International trade and Commodity Study Series No26 Group, World Bank Washington DC.

Mesike, S. (2010). Analysis of determinants of Rubber Export supply in NIgeria. MSC thesis in Ibadan: Unversity of Ibadan, pp 94-98.

Musila, J. (2004). The Common Market for eastern and Southern Africa and Kenya's Export trade. International Journal of Social Economics, 31(1/2). Athabasca University

Okoruwa, V. O. (2003). Determinants of Traditional Agricultural Exports In Nigeria: An Application of Co integration and Correction model. Quarterl Journal of International Agriculture, 42, 427-438.

Redding, S. A. (2002). Explaining Cross-Country Export Performance: International Linkages and Internal Geography. Seminar paper.

Sharma, K. (2000). Export Growth in India: Has FDI played a Role. Charles Sturt University Discussion Paper, No 816.

Tijani, A. A. (1999). A Co integration Analysis of Nigeria Cocoa Export Supply. Journal of rural Economics and Development, 13(1), 45-56.

Tyler, J. (1973). Manufactured export promotion in a semi-industrialized economy: Brazilian Case. Journal of Development Studies, 10(1) 3-15.

UNCTAD. (2005). Developing Countries in International Trade. Trade and Development Index 2005, New York and Geneva,United Nations .

UNCTAD. (2006). The Least Developed Countries Report, 2006. New York and Geneva, United Nations. 